\title{
Reading Transhistorical Performances: No Sugar (1984), Holy Day (2001) and Ngurrumilmarrmiriyu [Wrong Skin] (2010)
}

\section{Denise Varney}

Over thirty years ago, I saw a performance of the Australian Indigenous-authored play No Sugar (1986) in the cold bluestone-walled basement of Fitzroy Town Hall in inner-city Melbourne. The play was written by poet, playwright and political activist Jack Davis (1917-2000) and first performed at the Festival of Perth in February 1985. The play and its early performances share a timeframe with the publication of Reading the Country, although that is not to say they were connected. The play is set in the past, in 1929, and across spaces that Deleuze and Guattari would refer to as striated rather than nomadic. The action marks out lines that join a police station, a mission, government offices, clearings and a railway line. These are lines on country marked out and governed by the colonial apparatus. Yet No Sugar and Reading the Country can be said to share a history and a moment of intellectual and creative breakthrough which saw Indigenous perspectives and knowledge disrupt the surface of postcolonial Australia. Representing different time and space, but united on the margins of culture, both offer decentred ways of seeing and thinking. The representation of the Moore River Native Settlement in the southwest was far away from the openness of the Roebuck Plains in the northwest, captured in Reading the Country, but they both paved the way for radical changes 
such as the Mabo Decision and the continuing renewal and circulation of Indigenous knowledge.

In this article, I re-consider Jack Davis's groundbreaking intervention in the 1980 into the cultural dominance of the European perspective and the associated nexus between settler or European drama and realism in the field of Australian theatre and performance. I then discuss the millennial drama, Holy Day (2001) by Andrew Bovell, which appeared in the midst of the Reconciliation movement and Prime Minister John Howard's refusal to acknowledge the dispossession and suffering of Aboriginal peoples as a consequence of British colonisation. I then trace Jack Davis's influence through to Ngurrumilmarrmiriyu (Wrong Skin), a performance devised and performed in 2010 by Yolngu youth from Elcho Island in the Northern Territory.

\section{No Sugar (1986)}

Journalist Frank Devine noted in a tribute in The Australian shortly after Davis's death at the age of 83 that No Sugar was 'one of the plays on which the curtain never falls in the theatre of memory.' ${ }^{1}$ My experience of seeing the performance at the Fitzroy Town Hall was unforgettable and to this day I can place myself in my seat and replay fragments of the performance. This was due to the play's visceral recreation of the brutality of the Moore River Mission in Western Australia but also the palpable spatial experience for performer and spectator of being enclosed in the Fitzroy Town Hall basement. It was an embodied, affective feeling of imprisonment and violence. The sound of heavy police boots on the wooden floor, and the threat of the whip produced automatic flinching and a sense of alert wariness for what was to come.

The Moore River Mission was run by the Chief Protector of Aborigines, the hated A.O. Neville, initiator of the child removals that continued until the 1970 as reported in Bringing Them Home: Report of the National Inquiry into the Separation of Aboriginal and Torres Strait Islander Children from Their Families (1997). ${ }^{2}$ The actor playing Neville wore his double-breasted suit as a robe of power and ensured he stood over rather than beside or among people. The play is structured in three acts with several scenic changes 
across different locations marked out and illuminated in the cavernous town hall basement. There was a large Indigenous and non-Indigenous cast with Davis unflinchingly using racist names such as Topsy and Black Tracker and with dialogue in local languages. The narrative follows an extended family, the Mundays and the Millimurras, as they eke out a refugee life on the Government Well Aboriginal Reserve in Northam. The families are dependent on government rations and must adopt the deferential demeanour of the receiver in relation to the all-powerful giver. Along with the references to loss of land, working without wages and massacres is the reassertion of knowledge to do with culture, land and totems. There are recognised Song Men, Dance Men and Dreamtime stories. In one sequence in Act 2, the men paint up for a corroboree and a fire is built. Jimmy Munday sings his grandfather's song in language that is translated as a song that sings for 'the karra, you know, crabs, to come up the river and for the fish to jump up high so he can catch them in the fish traps'. ${ }^{3}$ This is followed by a dance sequence:

[JIMMY, JOE and SAM laugh. SAM jumps to his feet with the clapsticks.]

SAM: This one yahllarah! Everybody! Yahllarah!

[He starts a rhythm on the clapsticks. BLUEY plays didgeridoo. JIMMY and then JOE, join him dancing.]

Come on! Come on!

[He picks up inji sticks. The Nyoongahs, SAM, JIMMY and JOE, dance with them. BILLY joins in. They dance with increasing speed and energy, stamping their feet, whirling in front of the fire, their bodies appearing and disappearing as the paint catches the firelight. The dance becomes faster and more frantic until finally SAM lets out a yell and they collapse, dropping back to their positions around the fire. JIMMY coughs and pants painfully. $]^{4}$ 
The dance interlude not only interrupts the realist dramatic action but injects a different energy and bodily way of being into the performance that contrasts with the imposed demeanour of the colonial subject.

Theatre scholar Marc Maufort writes that in the 1980 s Jack Davis established 'the formal and thematic standards of the fledgling genre of Aboriginal drama', which notably questioned the foundations of European rationalism with the forging of 'a syncretic style fusing Western realism and Aboriginal myth'. ${ }^{5}$ Christopher Balme reads this syncretic style, also referred to as hybridity, as integral to Indigenous drama. ${ }^{6}$ In acknowledging Davis's contribution to Indigenous theatre and drama, director Wesley Enoch writes that his work 'inspired and trained us and showed us the potential of theatre to cross our traditional storytelling with our contemporary lives'. ${ }^{7}$ This syncretic style arrives at stunning new forms of Indigenous musical theatre in Ngurrumilmarrmiriyu [Wrong Skin]. But before moving onto that performance, I want to compare these performances with a non-Indigenous authored play that sits historically midway between the two at the turn of the millennium.

\section{Holy Day (2001)}

In the early 200os, John Howard's Liberal-National Coalition government refused to apologise for the suffering of the Stolen Generations of Aboriginal children, who were forcibly separated from family and country. In the face of an unrelenting prime minister, the Council for Aboriginal Reconciliation organised the Corroboree 2000 Bridge Walk across Sydney Harbour Bridge to raise public awareness of the cultural politics of colonisation. In the theatre, dramatists and theatre makers such as Wesley Enoch, Jane Harrison, Scott Rankin and Dallas Winmar honoured the Davis legacy by interrogating the representation of settler violence and the suffering of Aboriginal peoples. Andrew Bovell's Holy Day (2001), a play about colonial violence, grew out of this period but adds a non-Indigenous voice to the growing body of dramatic literature re-examining Australian history. Bovell's play is a historical drama set in the nineteenth century focusing on European settlement and the Frontier Wars. It was first 
performed at The Playhouse, Adelaide Festival Centre in 2001 in a production directed by Rosalba Clemente and with Rachael Maza and Melodie Reynolds as the two Aboriginal women, Linda and Obedience.

Holy Day presents European settlement as a lawless place 'six days ride to the nearest law'. ${ }^{8}$ As with many non-Indigenous authored and directed colonial themed plays, it begins with early nineteenth-century settlers experiencing hardship and alienation in the colony. The play's perspective is white but it increasingly highlights the perpetration of a reign of terror in which settlers massacre an Indigenous community and brutalise the young. The staging of abject horror and cruelty produces a shock aesthetic that seeks to distance the play from the secrecy surrounding official versions of colonisation.

In the opening scene, Elizabeth Wilkes, a Christian missionary's widow, stands on stage with the sound of thunder rumbling in the distance expressing a sense of abandonment in a place far away from God, England and the rhythms of Christian Holy Days. Her words are cryptic but inscribed with enough Christian fundamentalism to present a picture of righteous fanaticism: 'Do my justice, Lord, and fight my fight against a faithless people'; she goes on to imagine the day when: 'I will go to the altar of God. Then I shall eat of His body and drink of His blood, the blood of my gladness and joy ....'9 The incantation is followed by a gunshot and more thunder. It later unfolds that she has burnt down her husband's church and, as she anticipated, he has shot himself in despair. She then makes the claim that her child has been taken. The gothic constellation of thunder, gunshots, the burning church and the lost child takes the play into realm of the white colonial imaginary. As this schema dictates, the nearest Indigenous woman, Linda, will be assumed to have taken the child. But Bovell unsettles the white myth by continually refocusing suspicion back onto the white woman. There is more to the story of the missing child. Nora, the only other white woman in the area, and the owner of the Traveller's Rest, a shack for grog and sex, offers two explanations: that a postpartum mother full of melancholia might leave her child out in the scrub 'for the dingoes to steal away'; ${ }^{10}$ or, intuiting that her husband, the pastor, has had a furtive sexual liaison 
with the woman Linda, she is mad enough to kill the child and burn the church in revenge. The settlers, however, have their excuse to commit massacre. Aimed at the settler community of 2001 in the Howard era, the play paints colonial society as a lurid spectacle of violence beyond the boundaries of law, morality and humanity. Whether Holy Day produces a spectacle of violence that confronts but does not advance a case for reparative justice is the key critical dilemma of the play.

The white frontier is represented as the antithesis of the heroic founding of a nation. Fearful settlers maintain their precarious holdings; women are driven to kill their young. Beyond is the nebulous region referred to by settlers as the 'bush' where a deterritorialised Indigenous community has regrouped to witness the laughable if not tragic attempts to build fences and introduce sheep. ${ }^{11}$ The presence of the Indigenous gaze from the bush invites contemplation of a series of inversions that upset the conventional hierarchy of settler and native. Settlers feel the presence of 'moving shadows', 12 while for the Indigenous community 'white men on horses' are the harbingers of violent death. ${ }^{13}$ The Indigenous gaze challenges the settler view that the frontier is far away from judgement and retribution, and that there will be no memory of the events that take place.

If Elizabeth represents the classical Medea, the stranger driven to kill her child to avenge an unfaithful husband, the final scene takes the audience into Shakespearean tragedy. Obedience, the slave-named stolen Indigenous girl adopted by the Irish woman, is raped by a violent ex-convict, Nathanial Goundry, who cuts out her tongue. As with Lavinia in the tragedy Titus Andronicus, the violence occurs off stage. The final image is of Obedience facing the audience with 'her mouth bleeding, her stare vacant'. ${ }^{14}$

As a counterpoint to the bleeding Indigenous girl, the performance complicates its expression of colonial morality with further instance of settler violence towards its own young. Goundry, the violent ex-convict, has abducted and enslaved a blond-haired, 16-year-old boy, Edward Cornelius, whose tongue he has mutilated. The boy's experience thus parallels that of Obedience, whom he befriends and loves. Towards the end of the drama, station owner Thomas Wakefield advises 
a traveller to avert his gaze from visions that will haunt his waking mind. Non-Indigenous audiences of Holy Day are called on to hold their gaze and critically respond to history that can 'bleed' through modern drama and leave its stain on the present. ${ }^{15}$

Nevertheless, Holy Day, like many non-Indigenous authored plays about the past, represents that which Scott Rankin, creative director of Big hART, recently described as 'a double wounding'. ${ }^{16}$ This occurs when a white-made theatre piece represents the tragedy of European invasion and settlement and in doing so asks Indigenous performers to replay the role of victim, of the marginal character or the wounded abject object of the stage action. It also risks reducing suffering to voyeuristic spectacle. The play and its performance work on an aesthetics of brutality, directed at shocking a non-Indigenous audience, including politicians and policy makers, and disrupting the history of white settlement. The problem is that performers Rachael Maza and Melodie Reynolds remain fixed in time as vehicles for the education of the other rather than as agents of their own artistic expression. The performance stages the unresolved, and largely irreconcilable representation of colonisation through the European dramatic form.

\section{Ngurrumilmarrmiriyu [Wrong Skin] (2010)}

Ngurrumilmarrmiriyu [Wrong Skin] represents what Rankin refers to as 'indigenous cultural strength' and how 'remarkable men and women [are] saving languages and cultures'. ${ }^{17}$ The use of song and dance in recent Indigenous theatre marks a turning away from European models of dramatic realism and a preference for combining local cultures with popular media forms sourced from around the world to create joyous assertions of cultural survival. Following the critical acclaim of the stage and screen versions of Jimmy Chi's Bran Nue Dae, engagement beyond the borders of European Australian culture can be seen in two recent Indigenous works. Tony Briggs's The Sapphires, which tells the story of an Indigenous 'Motown' singing group that entertains the troops in Vietnam in the late 1960 s, was originally staged at the 2010 Adelaide Festival, and then adapted for film in 2012. Ngurrumilmarrmiriyu [Wrong Skin] is a multi-modal theatrical performance written 
and directed by British-born Nigel Jamieson in association with movement director Gavin Robins, Elcho Island community and cultural liaison director, Joshua Bond, and film and video designer, Scott Anderson. ${ }^{18}$ Made on the island in a collaboration between Nigel Jamieson and members of the Yolngu community, Ngurrumilmarrmiriyu [Wrong Skin] celebrates, but also historicises, the lived present of young islander men and women.

Central to the performance are the Chooky Dancers, a group of young Yolngu men from Elcho Island who in 2007 posted a parody of the 'Zorba the Greek' dance on YouTube, attracting a global audience of over 1.5 million viewers. Unlike a dance ceremony performed at large gatherings, where it is connected to song cycles that include Dreamtime stories, 'Zorba the Greek Yolngu Style' is more in the tradition of community entertainment. It is a lively, parodic synthesis of popular Greek and traditional Aboriginal dance combined with contemporary African-American hip-hop influences. The dance was originally performed by Anthony Quinn and Alan Bates in the film Zorba the Greek (1964). In the live performance and on YouTube, the Chooky Zorba is performed by nine young male dancers, who form a square grid formation rather than the arms-around-shoulder hold of the original. Their bodies are painted and they wear colourful loin cloths. Their feet are bare. The dancers move forwards and sideways to the music using arms and legs alternately, giving increasing emphasis to the steps as the music picks up pace. The dance displays a complex choreography involving synchronised movement, half turns, slides and athletic flexibility. There is much humour in the timing, in the ways the dancers extend or hold a formation and then break free from it. Where the Mexican-American Quinn and English Bates project iconic Greekness in the use of shoulder-to-shoulder movement, raised arms and finger clicking, the Chooky Dancers stomp and turn in a fusion of Indigenous dance and hip-hop, and remain straight-faced throughout.

The dance breaks up the performed monoculturalism of the original while blending and splicing in diverse movements without losing the Zorba rhythm. The dancers can be said to find new links in the form of fluent articulations between 
Indigenous and European movement repertoires while emphasising the parodic element of the performance and their own virtuosity, discipline and inventiveness. As I have written in an earlier piece on this dance, it is a compelling example of 'Indigeneity ... resignif[ing] European culture, asserting the performative power of the new version and celebrating the pleasure and freedom of the fluidity of movement, music, creativity and virtuosity.' ${ }^{19}$ Looking at the performance on YouTube again, now with over two million hits, its power over time, space and the medium of dance expands rather than diminishes with repetition. We see how bodies draw and dissolve lines and circles on the ground in embodied gestures of connection to country.

Thirty years on from Jack Davis's No Sugar, Ngurrumilmarrmiriyu features the talented, young and fit Chooky Dancers, whose theatre has moved to main city stages away from the basement of the Fitzroy Town Hall. The flow of digital cinematic and video imagery into the space of local culture and performance suggests the formation of youthful 'Yolngu' culture. Where Homi Bhaba suggests that colonised subjects use mimicry to unsettle the artistic domination of the Western canon, the Chooky dancers's expanded field is a parody of both global popular culture and European fine arts. Here the frame of reference extends beyond the colonial footprint to identify with global popular cultures as a release from the narrative frameworks and characters of spoken European drama. Of significance, therefore, is that the dance performances involve not only the integration of modern digital technology into performance, but also the reaffirmation of local myth and tradition. The 'ambivalence of mimicry', Bhaba's term for the desire for and threat of incorporation into the dominant colonial paradigm, is less palpable in the face of multiple lines of influence converging and transforming on the bodies of the dancers. ${ }^{20}$

Among the many adaptations that make up Ngurrumilmarrmiriyu is the romance narrative from Romeo and Juliet as experienced through the movie version of the musical West Side Story, featuring a stunning reworking of Anita's song 'I Want to Live in America'. Lead Chooky dancer, Lionel Dhulmanawuy, and actor, Rarriwuy Hick, play the 
lovers. Their elopement in Arnhem Land transposes Venetian and Puerto Rican families and gangs into an allegory of the spiritual, moral and abstract power of kinship law. Here a lesson on kinship and modern global culture are continuous rather than opposed in a way that rejects the linearity of conventional history and its categorisation of time.

For all its playful adaptation and parody, Ngurrumilmarrmiriyu performs important community work that simultaneously engages with young performers and dramatises themes of kinship within the wider project of land rights and self-determination. The emphasis on kinship in Ngurrumilmarrmiriyu and other recent works of Indigenous drama such as Wesley Enoch and Deborah Mailman's Seven Stages of Grieving, first performed in 1995, and Dallas Winmar's Yibiyung from 2008 can be understood as timely response to the politics of land rights as well as the pressures of modernity as much as if not more than attachments to tradition.

\section{Conclusion}

To conclude, I turn to the different kinds of audience responses the performances might create. Andrew Bovell's characterisation of the violent and abusive ex-convict, Nathanial Goundry, and his brutalised wounded teenage victims fills out the details of what we have come to identify as Australia's secret history, demonstrating the particularity of the violence of colonisation as it affected individuals and families. Goundry stands for the European consumed by power and desire committing acts of cruelty; he is a depised product of modern Australian drama. He takes the audience, and the performers, into the zone of horror in a work that puts pressure on John Howard and others who resile from the recognition of the impact of colonisation on Aboriginal peoples. Ngurrumilmarrmiriyu affirms Indigenous cultural strength while recognising the pressures of modernity on communities in the wider Northern Territory context. The performance 'argues' that young Yolngu men operate within a complex network of new modernities that impact on identity formation and cultural capital but they survive through being grounded in intergenerational relationships and connection 
to country. Having acquired expanded identities as dancers, minor global celebrities, and embodiments of the capitalised signifier 'Chooky Dancers', the performance celebrates the links between an island culture and mainland Australia; remote Indigenous community and global culture; and pre-settler, customary, pre-modern Australia and new forms of theatre. Jack Davis's play, first staged over thirty years ago, initiated formal innovations that continue to produce radical new extensions of the repertoire of Australian theatre and performance.

\section{Notes}

1 Frank Devine, 'Jack Davis leaves a Sweetener for a Better Country', The Australian, 30 March 2000, p. 11.

2 Australian Human Rights Commission, Bringing them Home: Report of the National Inquiry into the Separation of Aboriginal and Torres Strait Islander Children from Their Families, Canberra, April 1997, https://www.humanrights.gov. au/publications/bringing-them-home-preliminary\#down

3 Jack Davis, No Sugar, Currency Press, Sydney, 1988, p. 65-66.

4 Ibid., p. 66.

5 Marc Maufort, 'Unsettling Narratives: Subversive Mimicry in Australian Aboriginal Solo Performance Pieces', Antipodes, vol. 14, no. 2, December 200o, pp. 105-110, p. 105.

6 Christopher Balme, Decolonizing the Stage: Theatrical Syncretism and PostColonial Drama, Clarendon Press, Oxford 1999, p. 13.

7 Wesley Enoch, 'Davis's Legacy Lives On', Sydney Morning Herald, 20 March 2000, p. 14 .

8 Andrew Bovell, Holy Day, Currency Press, Sydney, 2001, p. 25.

9 Ibid., p. 1.

10 Ibid., p. 41.

11 Ibid.

12 Ibid., p. 11.

13 Ibid., p. 64 .

14 Ibid., p. 66; italics denote the stage direction.

15 Elin Diamond, 'Modem Drama/Modernity's Drama', Modern Drama, ed. Ric Knowles, Joanne Tompkins and W.B. Worthen, University of Toronto Press, Toronto, 2001, pp. 3-15, p. 11.

16 Andrew Stephens, 'Melbourne Festival 2014: Indigenous Community uses Theatre to Heal Old Wounds', Sydney Morning Herald, 26 September 2015.

17 Ibid.

18 Denise Varney, 'New and Liquid Modernities in the Regions of Australia: Reading Ngurrumilmarrmiriyu Wrong Skin', Australasian Drama Studies, vol. 58, 2011, pp. 212-27.

19 Ibid., p. 218.

20 Homi Bhaba, The Location of Culture, Routledge, London and New York, 2004, p. 129. 